\title{
INSTITUTIONAL BARRIERS TO BUSINESS ENTRY IN ADVANCED ECONOMIES
}

\author{
Tanja Kosi ${ }^{1}$, Štefan Bojnec ${ }^{2}$ \\ Department of Economics, Faculty of Management Koper, \\ University of Primorska, Cankarjeva 5, 6000 Koper, Slovenia \\ E-mails: ${ }^{1}$ tanja.kosi@fm-kp.si (corresponding author); ${ }^{2}$ stefan.bojnec@fm-kp.si
}

Received 14 July 2011; accepted 14 October 2011

\begin{abstract}
The paper empirically examines the impact of freedom from regulation in different institutional areas on business entry rate in 10 Organisation for Economic Cooperation and Development countries over the period 1995-2007. Employing the feasible generalized least squares econometric approach, it discloses a positive association between business entry and the overall institutional freedom. Economic freedom in different institutional areas, however, does not appear to have the same importance for business entry. Institutional freedoms that are the most beneficial for business creation are product market freedom, property rights freedom, and freedom from corruption. This implies that simple and inexpensive administration procedures, competitive product markets, and transparent and effective legal/judicial system help promote business creation. Business entry is also positively associated with macroeconomic prosperity in terms of employment growth and the development of information and communication technology industry.
\end{abstract}

Keywords: business entry, institutions, regulation, economic freedom, cross-country analysis, feasible generalized least squares method, OECD countries.

Reference to this paper should be made as follows: Kosi, T.; Bojnec, Š. 2013. Institutional barriers to business entry in advanced economies, Journal of Business Economics and Management 14(2): 317-329.

JEL Classification: M13, E02, C230, O50.

\section{Introduction}

A range of studies investigates the impact of different dimensions of entrepreneurship (measured by self-employment rates, Global Entrepreneur Monitor (GEM) indices, indicators of business dynamics etc.) on economic performance. Regression analyses of the influence of business creation on economic performance mostly focus on a single country (Foster et al. 2001; Disney et al. 2003; van Stel, Suddle 2008; Fritsch, Mueller 2008; Acs, Mueller 2008). The list of suchlike cross-country studies (including Scarpetta et al. 2002 and Bartelsman et al. 2004) is rather short, which is mostly due to data limitations. Cross-country and country-specific studies together provide convincing evidence that business creation positively affects economic performance in terms of total factor and labour productivity growth, employment growth and aggregate output growth. 
If entrepreneurship represents one of the sources of new jobs and economic growth, it shall not be hindered by the institutional framework. However, to guarantee a certain level of income and social security, equality and protection of health in a society, governments regulate product, labour and financial markets and impose taxes on personal income, business profits and other bases. High wages and taxes, strict employment protection legislation, strict technical standards, complicated administration procedures, inefficiency of the legal system in contract enforcement and underdevelopment of financial markets can distort entrepreneurial incentives (Lundström, Stevenson 2005: 253).

Empirical studies investigating the institutional and other determinants of entrepreneurship mostly measure this phenomenon by the self-employment or business ownership rate (Parker, Robson 2004; Kanniainen, Vesala 2005; Bruce, Mohsin 2006; Nyström 2008; Dickson et al. 2008) or by one of the GEM indices (Bjørnskov, Foss 2008; Sobel et al. 2007). The list of cross-country studies analyzing institutional determinants of business creation is rather limited. This study attempts to fill this gap by the econometric investigation of the impact of (freedom from) regulation in different institutional areas on business entry rate in 10 Organisation for Economic Co-operation and Development (OECD) countries ${ }^{1}$ over the period 1995-2007. Different specifications of the general regression equation are estimated by the feasible generalized least squares (FGLS) approach proposed by Parks (1967). The analysis is especially relevant for economic policymakers in continental European economies with traditionally stringent labour market regulation (LMR) and product market regulation (PMR), and important roles of government in the economy.

The rest of the paper consists of five sections. Section 2 reviews empirical literature examining the determinants of business entry. Section 3 describes variables used in the regression analysis and their data sources. Section 4 presents a framework for econometric analysis and describes the estimation approach. Results for different specifications of the general regression equation are presented in Section 5. Section 6 concludes.

\section{Literature review}

The amount of goods, new businesses, and patents generated from a given amount of economic inputs depends on the rules of the game (i.e. institutions) under which entrepreneurs operate (Sobel 2008: 645). As institutions govern the behaviour of individuals and businesses, they are likely to appear relevant for business dynamics. We classify them in the following groups: financial sector regulation, PMR, judicial system, property rights protection legislation, LMR, and fiscal regulation.

Rajan and Zingales (2003) emphasize the importance of financial development, related to the ease of obtaining finance for a sound entrepreneurial project and the confidence with which investors anticipate an adequate return. They argue that a well-developed

\footnotetext{
${ }^{1}$ The set of 10 OECD countries include nine European Union (EU) countries (Belgium, Denmark, Finland, France, Germany, Ireland, Italy, the Netherlands, and the United Kingdom) and the United States.
} 
financial system weakens the opposition of incumbent businesses and facilitates the entry of newcomers. Klapper et al. (2006) empirically show for 21 European countries that financial sector development positively affects new business creation in sectors that are more dependent on external financing. Alfaro and Charlton (2010) analyse the same relationship using firm-level data for 98 countries referring to years 1999 and 2004 . They find that reducing restrictions on international capital flows enhances business entry. Similar is found by Aghion et al. (2007) and Chavis et al. (2010).

PMR refers to a set of regulations - the state control of business enterprises, legal and administrative barriers to entrepreneurship, and barriers to international trade and investment - that might restrict competition in the product markets (Conway et al. 2006: 9). Scarpetta et al. (2002) empirically confirm a negative influence of PMR on business entry, especially on the entry of small and medium-sized businesses. Klapper et al. (2006) provide a cross-country study on the role of bureaucratic requirements to register a limited liability company. Using the industry-level entry rates for 3 million firms from 21 European countries and a sample of firms from the United States for the years 1998 and 1999, they show that costly entry regulations hamper the creation of new firms. More evidence on the adverse effect of PMR on the setting up of businesses is provided by Djankov et al. (2002), Desai et al. (2003) and Loayza et al. (2005). Studies in general conclude that detailed and costly bureaucratic processes related to licence and permission applications, and complicated procedure for legal registration of a business might divert potential entrepreneurs from starting their own business. However, bureaucratic entry barriers have been shown to impede entry in countries with relatively little corruption, while in corrupt countries entry barriers can be circumvented (Djankov et al. 2002; Klapper et al. 2006). But corruption itself can act as a powerful barrier to the entry of new businesses, as shown by Campos et al. (2010).

Another factor that might affect business creation is protection of intellectual property. Strong patent protection, for example, excludes imitators for a certain period out of the market and in this way protects incumbent businesses that own the patents. Small entrants often do not have enough finance or intellectual capital to invent new products or processes and might see their business opportunity as imitators. From this perspective, strong patent protection can impede business entry. On the other hand, individuals might be motivated to innovate and enter the market - despite being small - if they know that the output of their research will be legally protected. Klapper et al. (2006: 620) empirically show that countries with better protection of intellectual property have more entry in research and development $(\mathrm{R} \& \mathrm{D})$ intensive industries.

$L M R$ in the form of employment protection laws might affect industries in different directions. Compliance with employment protection laws prevents a business from firing its employees or makes it costly to do so. Strong employment protection might be particularly costly for small businesses, which are expected to face bigger problems with keeping their employees through economic downturns than their larger counterparts do. On the other hand, employment protection laws protect employees and give them the confidence to join small and newly born businesses (Klapper et al. 2006: 619-620). Scarpetta et al. (2002), Haltiwanger et al. (2006), Klapper et al. (2006) and 
Aghion et al. (2007) provide the convincing empirical evidence that strong employment protection hampers the entry of small- and medium-sized firms, in particular in labour intensive industries.

A study by Loayza et al. (2005), using industry-level and country-level data for the manufacturing sector for the United States and 12 European and Latin American countries for the period 1990-2001, confirms a negative impact of LMR on business entry but gives no robust evidence regarding the direction of the impact of fiscal regulation on firm dynamics.

Using data for the United States over the period 1992-2001, Campbell and Rogers (2007) empirically confirm a positive impact of the overall level of economic freedom, as measured by the Fraser Institute's economic freedom index, on the rate of net business formation.

Our study complements the findings of reviewed studies by examining the link between (freedom from) regulation in different institutional areas and business creation in 10 OECD countries over the period 1995-2007. It contributes to the policy debate on the effectiveness of alternative institutional settings on entrepreneurship in the form of business creation.

\section{Data description}

To measure business creation, we employ the business entry rate (entry, in \%) data from the International Benchmark of Entrepreneurs (IBE) database compiled by the Dutch institute EIM Business and Policy Research (EIM 2010). The IBE entry rate is calculated as the number of enterprise entries divided by the total number of active enterprises in a certain period, where an entry is defined as establishment of a new enterprise, for which at least one person works not less than one hour a week. The database includes all incorporated and unincorporated non-agricultural enterprises.

To measure the degree of freedom and flexibility of different institutions that might affect business creation, we use the Heritage Foundation's (2011) annual data on ten subindices that add up to a composite economic freedom index (EFI). We organize these sub-indices into six groups and arrive at the following economic freedom indicators:

- financial freedom indicator (FinFree), calculated as an unweighted average of the monetary freedom index and the financial freedom index;

- product market freedom indicator (ProdFree), calculated as an unweighted average of the business freedom index, trade freedom index and investment freedom index;

- fiscal freedom indicator (FisFree), calculated as an unweighted average of the fiscal freedom index and government spending index;

- labour market freedom index (LabFree);

- property rights freedom index (PropFree);

- freedom from corruption index (CorrFree).

Each of the indicators/indices takes the value from 0 to 100 , where 100 indicates the maximum freedom. 
Since the Heritage Foundation (2011) has measured the labour market index only since 2005, we decided to replace it with other measure of labour market freedom. The labour market freedom indicator (LabFree) used in this study is calculated as a simple average of rescaled values of three labour market indicators provided by the OECD (2010a, 2010b, 2010c): employment protection legislation indicator (epl), trade-union density (tud) and the gross unemployment benefit replacement rate (ubrr). As higher values of these OECD indicators imply more stringent LMR, each of the indicators is first rescaled according to the following formula: $100^{*}\left(x_{\max }-x_{i}\right) /\left(x_{\max }-x_{\min }\right)$ and then used as one of the components of LabFree. LabFree can therefore take the values between 0 and 100; the closer it gets to 100, the less stringent is LMR.

In addition to the degree of economic freedom and flexibility of institutions, business creation can be influenced by a set of other variables. Empirical studies of business dynamics (e.g. Scarpetta et al. 2002; Bartelsman et al. 2003; Brandt 2004) suggest that entry rates tend to be higher in services than in manufacturing industries. In our regression analysis, the industry structure is taken into account by controlling for the share of employment in the business service sector in total economy's employment (eservice, in $\%$ ). Entry rates also tend to be higher for younger industries (e.g. information and communication technology - ICT). Development of ICT and other technologies is expected to have positive impact on economic performance of other industries of the economy (Ginevičius, Podvezko 2004). Positive spillover effects of ICT development may in turn promote business entry rate in different industries. Therefore, we add the share of ICT manufactures in total economy's employment (eictman, in \%) to the set of control variables. The data source for eictman and eservice is OECD (2009b).

Theoretically, unemployment (unempl, in \%) can have two opposite effects on business creation. An unemployed person may be pushed into starting his own business, which implies a positive impact of unemployment on the business entry rate. At the same time, a higher level of unemployment may reduce demand for goods and services, which in turn decreases the rate of business creation (Reynolds et al. 1994). The net impact of unemployment on business creation is theoretically ambiguous (Sutaria, Hicks 2004). Using Finish individual-level data, Ritsilä and Tervo (2002) show that personal unemployment stimulates individuals to become self-employed, while a high national level of unemployment decreases the likelihood of new firm formation. We use OECD (2009a) data for unempl (in \%).

Bigger economies are likely to exhibit lower entry rates relative to small economies, since the establishment of a new branch by an existing business in another region is not recognized as a business entry, while it would be recognized if the region was beyond the international border (Eurostat-OECD 2008: 10-11). In analyzing the impact of institutions on business creation we thus control also for the size of population (used in logarithmic form, lnpop). The source of data for population (in millions) is PWT 6.3 (Heston et al. 2009). Beside the size of population, we also control for its growth (popgr, in \%). Sutaria and Hicks (2004), Acs and Armington (2002) and Reynolds (1994) suggest that population change positively affects the business entry rate. 
Higher openness (open, in \%) of a country to international trade implies higher competitive pressure for businesses but at the same time offers more business opportunities on international product markets (Colantone, Sleuwaegen 2010). The direction of the impact of trade openness on business entry is a priori ambiguous. The data for openness are taken from PWT 6.3 (Heston et al. 2009) and express the share of total real value of trade - imports plus exports - in real GDP at constant prices.

Lastly, we expect business entry to be affected by macroeconomic fluctuations. Since the aggregate output growth and the growth of output per capita have shown to be positively affected by business dynamics (Klapper et al. 2010; Loayza et al. 2005), the volatility of gross domestic product (per capita) is expected to be endogenous to the business entry equation. Employment growth seems to be less subject to endogeneity problems. Namely, a great share of entering businesses tends to be small relative to incumbents (Brandt 2004; Bartelsman et al. 2004), which means that business creation affects a minor share of total employment growth (Scarpetta et al. 2002). An alternative way of controlling for at least part of business cycle fluctuations is to take into account the annual change in terms of trade. The latter is calculated as a difference between the annual growth in the export price index $(P X)$ and the annual growth in the import price index $(P M):$ TOTch $=\Delta \ln T O T=\Delta \ln (P X / P M)=\Delta \ln P X-\Delta \ln P M$. Data for the employment growth rate (emplgr, in \%) and data for import and export prices used for calculating TOTch (in \%) are obtained from OECD (2009a, 2010c).

\section{Econometric strategy}

With the regression analysis, we aim to verify if and how selected institutional determinants affect the business creation. This is done by estimating different variants of the general regression equation:

$$
\text { entry }_{i t}=\alpha+\mathbf{I N S}_{i t} \beta+\mathbf{M V}_{i t} \gamma+a_{i}+\varepsilon_{i t},
$$

on time-series cross-section (TSCS) data covering 10 OECD countries over the period 1995-2007. Hereby, the subscript $i$ denotes a country, and $t$ stands for a time period; $\varepsilon_{i t}$ is the white noise error term, while $a_{i}$ presents country-specific effects (included when necessary and appropriate). The dependent variable, entry, is the business entry rate (in \%). INS is a vector of institutions of economic freedom. MV is a vector of relevant macroeconomic control variables, which includes the share of ICT manufactures in total economy's employment (eictman, in \%), the share of business service sector in total economy's employment (eservice, in \%), the rate of unemployment (unempl, in $\%$ ), trade openness (open, in \%), the logarithm of the size of population (lnpop, mio), population growth (popgr, in \%), employment growth (emplgr, in \%), and the annual change in terms of trade (TOTch, in \%).

Equation (1) is the most general variant of the regression equation. We estimate different specifications of equation (1) with combinations of control variables that satisfactorily explain the variance of the dependent variable and satisfy certain statistical properties. Fisher's test for the presence of a panel unit root for the business entry rate (Maddala, $\mathrm{Wu}$ 1999) rejects the null hypothesis of the presence of a unit root for all considered 
cases: driftless random walk, random walk with drift, and trend ${ }^{2}$. We may therefore conclude that the IBE entry rate follows a stationary process. Since many of the explanatory variables are also stationary, we estimate equation (1) on original rather than transformed data.

A full unconditional fixed effect (FE) regression of the business entry rate discloses that major part of the total variance in the business entry rate is due to country-specific effects. We are interested to find out to which extent these effects can be explained by institutional variables that vary across countries, but show little movement over time. Since the FE model observes only within-country data variation, the effects of timeinvariant variables on business entry will be estimated poorly due to high collinearity with country-specific effects. When the business entry rate is regressed solely on the composite index of economic freedom (IFE) and the control variables, we take into account country-specific effects to lower the risk of omitted variable bias. But when the set of explanatory variables includes different institutions of economic freedom, country-specific effects are omitted.

While the basic random effect (RE) model and FE model can be very useful for panel data, they do not deal with the important issues of heterogeneity in TSCS data. Namely, our dataset might suffer from autocorrelation, groupwise heteroskedasticity, and crosssectional dependence. The diagnostic checks ${ }^{3}$ for chosen variants of the regression equation (1) show that our data significantly violate the assumptions of autocorrelation and (groupwise) homoskedasticity. Accordingly, we estimate the regression equation (1) taking the FGLS approach proposed by Parks (1967) that corrects the standard errors for autocorrelation of order 1 (AR(1)), and groupwise heteroskedasticity.

To make sure that unemployment, as an explanatory variable, does not suffer from the endogeneity problem ${ }^{4}$, we perform the Granger (1969) test of (non)causality. The results ${ }^{5}$ suggest that business entry does not Granger cause unemployment but rather than the other way around.

\section{Description and interpretation of the econometric results}

Table 1 reports the estimation results for six specifications of the general regression equation, where macroeconomic fluctuation is measured by the employment growth rate. The estimation of comparable variants of equation (1) that use percentage change in terms of trade as a proxy for macroeconomic fluctuation yield similar estimates of the regression coefficients of institutional variables ${ }^{6}$.

\footnotetext{
2 The results of Fisher's test are available from the authors upon request.

${ }^{3}$ The results of the test of autocorrelation in the error term and modified Wald statistic for groupwise heteroskedasticity in TSCS FGLS regression model (Baum 2001; Greene 2003: 598) confirm the presence of both AR(1) and groupwise heteroskedasticity in the residuals of all variants of equation (1).

${ }^{4}$ We thank the anonymous referee for pointing out the endogeneity problem and suggesting additional testing.

${ }^{5}$ The results are available from the authors upon request.

${ }^{6}$ The results are available from the authors upon request.
} 
Table 1. Results of the regression analysis

\begin{tabular}{|c|c|c|c|c|c|c|c|c|}
\hline \multirow{2}{*}{$\begin{array}{l}\text { Explanatory } \\
\text { variables: }\end{array}$} & \multicolumn{8}{|c|}{ Regression equation specification; Dependent variable: entry } \\
\hline & (1) & $(1)+F E$ & (2) & $(2)+F E$ & (3) & (4) & (5) & (6) \\
\hline$\overline{E F I}$ & $0.1426^{* * *}$ & $0.0952 * * *$ & $0.1440 * * *$ & $0.0935^{* * *}$ & & & & \\
\hline ProdFree & & & & & $0.1080^{* * *}$ & $0.1067 * * *$ & $0.0967 * * *$ & $0.0955^{* * *}$ \\
\hline FinFree & & & & & 0.0113 & 0.0129 & 0.0148 & 0.0141 \\
\hline FisFree & & & & & 0.0015 & -0.0002 & & \\
\hline ProperFree & & & & & $0.0394 * *$ & $0.0399 * *$ & $0.0437 * *$ & $0.0429 * *$ \\
\hline CorrFree & & & & & $0.0123^{*}$ & $0.0126^{* *}$ & $0.0145^{* *}$ & $0.0143^{* *}$ \\
\hline LabFree & & & & & & & 0.0198 & 0.0224 \\
\hline eservice & $-0.1859 * *$ & -0.0738 & $-0.2188^{* * *}$ & -0.1110 & $-0.2223 * * *$ & $-0.2368 * * *$ & $-0.2720 * * *$ & $-0.2648 * * *$ \\
\hline eictman & $0.9317 *$ & 0.9174 & $1.0294 * *$ & $1.0419 *$ & $1.0691 *$ & $1.1068^{*}$ & 0.8937* & 0.8574 \\
\hline unempl & $-0.2229 * * *$ & -0.0407 & $-0.2386^{* * *}$ & -0.0405 & $-0.3269^{* * *}$ & $-0.3341 * * *$ & $-0.3522 * * *$ & $-0.3443^{* * *}$ \\
\hline lnpop & -0.2062 & -1.7825 & & & & 0.0841 & & -0.0531 \\
\hline open & & & 0.0043 & 0.0061 & -0.0019 & & 0.0006 & \\
\hline popgr & 1.0390 & $2.2721^{* *}$ & 0.9978 & $2.2600 * *$ & $1.0921^{*}$ & $1.1072 *$ & 0.8796 & 0.8671 \\
\hline emplgr & $0.1176^{*}$ & $0.1308^{* *}$ & $0.1211^{* *}$ & $0.1338 * *$ & $0.1536^{* *}$ & $0.1540 * *$ & $0.1707 * * *$ & $0.1648 * *$ \\
\hline constant & $9.1308 * *$ & 19.8658 & $7.9256 * *$ & 4.0823 & 7.7190* & 7.2581 & 9.1177* & 9.4949* \\
\hline$\overline{\mathrm{N}}$ & 116 & 116 & 116 & 116 & 116 & 116 & 116 & 116 \\
\hline $\begin{array}{l}\text { Wald } \mathrm{Chi}^{2} \\
\text { (sig.) }\end{array}$ & $\begin{array}{l}129.75 \\
(0.000) \\
\end{array}$ & $\begin{array}{l}329.40 \\
(0.000) \\
\end{array}$ & $\begin{array}{l}127.11 \\
(0.000) \\
\end{array}$ & $\begin{array}{l}338.65 \\
(0.000) \\
\end{array}$ & $\begin{array}{l}157.04 \\
(0.000) \\
\end{array}$ & $\begin{array}{l}152.94 \\
(0.000) \\
\end{array}$ & $\begin{array}{l}204.11 \\
(0.000) \\
\end{array}$ & $\begin{array}{l}188.68 \\
(0.000) \\
\end{array}$ \\
\hline
\end{tabular}

Note: The equations are estimated by FGLS approach. + FE denotes that the model includes the fixed (country-specific) effects. Standard errors are adjusted for groupwise heteroskedasticity and common AR(1). Correcting the standard errors for panel-specific AR(1) gives similar results.

* Regression coefficient is significant at the $10 \%$ (2-tailed), ${ }^{* *}$ Regression coefficient is significant at the $5 \%$ (2-tailed), *** Regression coefficient is significant at the $1 \%$ (2-tailed).

Source: Own estimation.

The results in Table 1 suggest that overall economic freedom (EFI) significantly positively affects business creation. The estimated regression coefficients suggest that increasing the EFI from 60.2 to 78.0 (which is analogue to moving from France with the lowest $E F I$ to the United States with the highest $E F I$ ) increases the business entry rate by 1.7 to 2.6 percentage point (depending on the variant of the model). Since the composite economic freedom index gives little specific information that is useful for economic policy makers, we break it down into indicators of freedom in specific institutional areas.

Product market freedom (ProdFree) significantly positively affects business entry. The results suggest that increasing ProdFree from 52.7 (which is the lowest value in the group reached by France) to 61.7 (which is the highest freedom in the group reached by Ireland) increases the business entry rate by about 1 percentage point. The direction of the impact corresponds to the findings of Klapper et al. (2006) and Scarpetta et al. (2002). 
Protection of property rights (ProperFree) significantly positively affects business entry. The estimates of the regression coefficient suggest that increasing ProperFree from 66.7 (reached by Italy with the least protected or humble property rights) to 90.0 (which is the value reached in seven countries with the highest protection of property rights in the group) increases the business entry rate by about 1 percentage point. A positive impact of protection of property rights is in line with the results of the study by Klapper et al. (2006). It suggest that entering businesses gain more from the protection of property rights arising from innovation and business entry than they lose due to being excluded as imitators for a certain period out of the market.

Freedom from corruption (CorrFree) significantly positively affects business entry (as previously shown by Campos et al. 2010) but the effect appears to be modest. Increasing the value of the freedom from corruption index from the lowest value in the group reached by Italy (51.6) to the highest value in the group reached by Denmark (95.2) increases the business entry rate by 0.5 to 0.6 percentage point.

Labour market freedom indicator (LabFree) and financial freedom index (FinFree) have positive but small regression coefficients, which are statistically insignificant. The regression coefficient of the index of fiscal freedom (FisFree) is insignificant with unstable sign.

The results suggest that the service sector employment share (eservice) negatively affects business entry. This result is at odds with the stylized fact that business entry is higher in service than manufacturing sector presented by Scarpetta et al. (2002) and Brandt (2004). In line with the results of the latter studies, the share of ICT manufactures in total economy's employment (eictman) significantly positively affects the business entry rate.

The unemployment rate (unempl) shows a negative influence on business entry, as suggested by Ritsilä and Tervo (2002). This result implies that at the macro level the pull effect of unemployment on business creation prevails over the push effect. Employment growth that serves as a proxy for macroeconomic movements significantly positively affects the business entry rate.

The size of population (lnpop) shows a negative impact on the business entry rate as suggested by Eurostat-OECD (2008: 10-11), but the regression coefficient does not appear to be statistically significant. As previously found by Sutaria and Hicks (2004), Acs and Armington (2002) and Reynolds (1994), the growth in population (popgr) positively affects the business entry rate. The sign of this impact is stable, but the significance parameter lacks robustness.

Lastly, the regression coefficient pertaining to trade openness (open) is positive, but statistically insignificant. This is at least partly because the ProdFree index comprises a measure of obstacles to international trade and thus already explains a part of variation in the business entry rate related to trade openness. 


\section{Conclusions}

The results of the regression analysis, using TSCS data for 10 OECD countries over the period 1995-2007, corroborate theoretical hypothesis that freedom from regulation in general positively affects business creation. Economic freedom in different institutional areas, however, does not appear to have the same importance for business entry.

In line with previous research, we find a positive impact of product market freedom or, inversely, a negative impact of PMR on business entry. The results, however, do not imply that countries should deregulate their product markets in all directions. The decision on the withdrawal of a certain legal act regulating the production and trade of a certain good shall be made based on the comparison of the benefits of such regulation for the society and its costs in terms of lower business incentives, time and money wasted by firms on complicated administrative procedures, and the additional operational and transaction costs due to larger administrative apparatus.

Estimation results also disclose that the protection of property rights positively affects business entry, which supports the prevailing findings from previous studies. This is the only type of regulation that appears beneficial for business start-ups. It assures owners and investors that their property rights will be respected and protects innovators against copying or imitation (at least) within their country.

We find no evidence on the significant impact of financial, labour market and fiscal freedom on the business entry rate. In line with expectations, corruption is shown to have a modest negative impact on business creation.

The main results of the study are robust and in general match theoretical expectations and previous empirical evidence but are subject to few limitations. Employed institutional indicators are based on surveys and thus at least partly reflect subjective judgement of respondents. Furthermore, the use of country-level data does not enable to completely capture the industry structure of the economies and to unravel responses to regulations at the industry level. Finally, the study provides policy-makers with recommendations on the direction of development in the main economic institutional areas but says little about the how process of deregulation should be governed. These are the issues that shall be addressed in further research.

\section{References}

Acs, Z. J.; Armington, C. 2002. The determinants of regional variation in new firm formation, Regional Studies 36(1): 33-45. http://dx.doi.org/10.1080/00343400120099843

Acs, Z. J.; Mueller, P. 2008. Employment effects of business dynamics: Mice, Gazelles and Elephants, Small Business Economics 30(1): 85-100. http://dx.doi.org/10.1007/s11187-007-9052-3

Aghion, P.; Fally, T.; Scarpetta, S. 2007. Credit constraints as a barrier to the entry and post-entry growth of firms, Economic Policy 22(52): 731-779.

http://dx.doi.org/10.1111/j.1468-0327.2007.00190.x

Alfaro, L.; Charlton, A. 2010. International financial integration and entrepreneurial firms' dynamics, Harvard Business School Working Paper No. 07-012: 30. Harvard Business School.

Bartelsman, E.; Haltiwanger, J.; Scarpetta, S. 2004. Microeconomic evidence of creative destruc- 
tion in industrial and developing countries. Development Economics Research Group, Policy Research Working Paper Series 3464: 49. The World Bank.

Bartelsman, E.; Scarpetta, S.; Schivardi, F. 2003. Comparative analysis of firm demographics and survival: micro-level evidence for the OECD countries, OECD Economics Department Working Papers 348: 61. OECD Publishing. http://dx.doi.org/10.1787/010021066480

Baum, C. F. 2001. Residual diagnostics for cross-section time series regression models, The Stata Journal 1(1): 101-104.

Bjørnskov, C.; Foss, N. 2008. Economic freedom and entrepreneurial activity: some cross-country evidence, Public Choice 134(3): 307-328. http://dx.doi.org/10.1007/s11127-007-9229-y

Brandt, N. 2004. Business dynamics, regulation and performance, OECD Science, Technology and Industry Working Papers 2004/3: 33. OECD Publishing. http://dx.doi.org/10.1787/573033480640

Bruce, D.; Mohsin, M. 2006. Tax policy and entrepreneurship: new time series evidence, Small Business Economics 26(5): 409-425. http://dx.doi.org/10.1007/s11187-005-5602-8

Campbell, N. D.; Rogers, T. 2007. Economic freedom and net business formation, Cato Journal 27(1): 23-36.

Campos, N. F.; Estrin, S.; Proto, E. 2010. Corruption as a barrier to entry: theory and evidence, IZA Discussion Papers 5243: 23. Institute for the Study of Labor (IZA).

Chavis, L.; Klapper, L.; Love, I. 2010. The impact of the business environment on young firm financing, Policy Research Working Paper Series 5322: 39. The World Bank.

Claessens, S.; Laeven, L. 2003. What drives bank competition? Some international evidence, Policy Research Working Paper Series 3113: 33. The World Bank.

Colantone, I.; Sleuwaegen, L. 2010. Entry and exit of firms in a global economy: a cross-country and cross-industry analysis, Journal of International Business Studies 41(7): 1240-1257.

http://dx.doi.org/10.1057/jibs.2009.105

Conway, P.; Janod, V.; Nicoletti, G. 2006. Product market regulation in OECD countries: 1998 to 2003, OECD Economics Department Working Papers 419: 61. OECD Publishing.

http://dx.doi.org/10.1787/783417550348

Desai, M.; Gompers, P.; Lerner, J. 2003. Institutions, capital constraints and entrepreneurial firm dynamics: evidence from Europe, NBER Working Paper 10165: 35. National Bureau of Economic Research, Inc.

Dickson, P. H.; Solomon, G. T.; Weaver, K. M. 2008. Entrepreneurial selection and success: does education matter?, Journal of Small Business and Enterprise Development 15(2): 107-124. http://dx.doi.org/10.1108/14626000810871655

Disney, R.; Haskel, J.; Heden, Y. 2003. Restructuring and productivity growth in UK manufacturing, Economic Journal 113(489): 666-694. http://dx.doi.org/10.1111/1468-0297.t01-1-00145

Djankov, S.; La Porta, R.; Lopez-de-Silanes, F.; Shleifer, A. 2002. The regulation of entry, Quarterly Journal of Economics 117(1): 1-37. http://dx.doi.org/10.1162/003355302753399436

EIM. 2010. International Benchmark of Entrepreneurship [online], [cited 2 September 2009]. Available from Internet: http://www.entrepreneurship-sme.eu/index.cfm/1,76,0,0,html/Datasets.

Eurostat-OECD. 2008. Eurostat-OECD Manual on Business Demography Statistics 2007. Paris: OECD.

Foster, L.; Haltiwanger, T.; Krizan, C. J. 2001. Aggregate productivity growth: lessons from microeconomic evidence, in C. R. Hulten, E. R. Dean, M. J. Harper (Eds.). New Developments in Productivity Analysis. Chicago: University of Chicago Press, 303-372.

Fritsch, M.; Mueller, P. 2008. The effect of new business formation on regional development over time: the case of Germany, Small Business Economics 30(1): 15-29.

http://dx.doi.org/10.1007/s11187-007-9067-9 
Ginevičius, R.; Podvezko, V. 2004. Complex evaluation of the use of information technologies in the countries of Eastern and Central Europe, Journal of Business Economics and Management 5(4): 183-191.

Granger, C. W. J. 1969. Investigating causal relations by econometric models and cross-spectral methods, Econometrica 37(3): 424-438. http://dx.doi.org/10.2307/1912791

Greene, W. H. 2003. Econometric analysis. $5^{\text {th }}$ ed. New Jersey: Prentice Hall.

Haltiwanger, J.; Scarpetta, S.; Schweiger, H. 2006. Assessing job flows across countries: the role of industry, firm size and regulations, Policy Research Working Paper Series 4070: 55. The World Bank.

Heston, A.; Summers, R.; Aten, B. 2009. Penn World Table Version 6.3. Center for International Comparisons of Production, Income and Prices at the University of Pennsylvania, August 2009 [online], [cited 12 March 2010]. Available from Internet: http://pwt.econ.upenn.edu/php_site/ pwt_index.php

Kanniainen, V.; Vesala, T. 2005. Entrepreneurship and labor market institutions, Economic Modelling 22(5): 828-884. http://dx.doi.org/10.1016/j.econmod.2005.05.002

Klapper, L.; Amit, R.; Guillén, M. F. 2010. Entrepreneurship and firm formation across countries, in International differences in entrepreneurship. Cambridge: National Bureau of Economic Research, 129-158.

Klapper, L.; Laeven, L.; Rajan, R. 2006. Entry regulation as a barrier to entrepreneurship, Journal of Financial Economics 82(3): 591-629. http://dx.doi.org/10.1016/j.jfineco.2005.09.006

Loayza, N. V.; Oviedo, A. M.; Servén, L. 2005. Regulation and microeconomic dynamics; a comparative assessment for Latin America. Mimeo. Washington: The World Bank.

Lundström, A.; Stevenson, L. A. 2005. Entrepreneurship policy: theory and practice. New York: Springer.

Maddala, G. S.; Wu, S. 1999. A comparative study of unit root tests and a new simple test, Oxford Bulletin of Economics and Statistics 61(0): 631-652.

http://dx.doi.org/10.1111/1468-0084.61.s1.13

Nyström, K. 2008. The institutions of economic freedom and entrepreneurship: evidence from panel data, Public Choice 136(3): 269-282. http://dx.doi.org/10.1007/s11127-008-9295-9

OECD. 2009a. OECD factbook 2009. Paris: Organisation for Economic Co-operation and Development.

OECD. 2009b. Industry and services STAN Indicators. Paris: Organisation for Economic Cooperation and Development.

OECD. 2010a. The OECD Summary Measure of Benefit Entitlements, 1961-2007 [online], [cited 5 February 2011]. Available from Internet: http://www.oecd.org/dataoecd/52/9/42625593.xls.

OECD. 2010b. Labour Statistics: Trade Union Density [online], [cited 5 February 2011]. Available from Internet: http://stats.oecd.org/Index.aspx.

OECD. 2010c. Economic outlook 2010. Paris: Organisation for Economic Co-operation and Development.

Parker, S. C.; Robson, M. T. 2004. Explaining international variations in self-employment: evidence from a panel of OECD countries, Southern Economic Journal 71(2): 287-301.

http://dx.doi.org/10.2307/4135292

Parks, R. W. 1967. Efficient estimation of a system of regression equations when disturbances are both serially and contemporaneously correlated, Journal of the American Statistical Association 62(318): 500-509. http://dx.doi.org/10.1080/01621459.1967.10482923

Rajan, R.; Zingales, L. 2003. The emergence of strong property rights: speculation from history, NBER Working Papers 9478: 36. National Bureau of Economic Research, Inc. 
Reynolds, P. 1994. Autonomous firm dynamics and economic growth in the United States, 19861990, Regional Studies 28: 429-442. http://dx.doi.org/10.1080/00343409412331348376

Reynolds, P.; Storey, D.; Westhead, P. 1994. Cross-national comparisons of the variation in new firm formation rates, Regional Studies 28: 443-456.

http://dx.doi.org/10.1080/00343409412331348386

Ritsilä, J.; Tervo, H. 2002. Effects of unemployment on new firm formation: micro-level panel data evidence from Finland, Small Business Economics 19(1): 31-40.

http://dx.doi.org/10.1023/A:1015734424259

Scarpetta, S.; Hemmings, P; Tressel, T.; Woo, J. 2002. The role of policy and institutions for productivity and firm dynamics: evidence from micro and industry data, OECD Economics Department Working Papers 329: 61. OECD Publishing. http://dx.doi.org/10.1787/547061627526

Sobel, R. S. 2008. Testing Baumol: Institutional quality and the productivity of entrepreneurship, Journal of Business Venturing 23(6): 641-655. http://dx.doi.org/10.1016/j.jbusvent.2008.01.004

Sobel, R. S.; Clark, J. R.; Lee, D. R. 2007. Freedom, barriers to entry, entrepreneurship, and economic progress, Review of Austrian Economics 20(4): 221-36.

http://dx.doi.org/10.1007/s11138-007-0023-3

Sutaria, V.; Hicks, D. A. 2004. New firm formation: dynamics and determinants, The Annals of Regional Science 38: 241-262. http://dx.doi.org/10.1007/s00168-004-0194-9

The Heritage Foundation. 2011. Index of Economic Freedom [online], [cited 15 April 2011]. Available from Internet: http://www.heritage.org/

van Stel, A.; Suddle, K. 2008. The impact of new firm formation on regional development in the Netherlands, Small Business Economics 30(1): 31-47.

http://dx.doi.org/10.1007/s11187-007-9054-1

Tanja KOSI is an Assistant Professor of Economics at Faculty of Management, University of Primorska, Slovenia. Her research interests include the role of labour market institutions and economic policies, labour market performance and macroeconomic perspectives on entrepreneurship. She has published four original scientific articles and attended several international scientific conferences.

Štefan BOJNEC is a Full Professor of Economics at Faculty of Management at the University of Primorska, Slovenia. He published extensively on various aspects of business, economics and management in transitional Central and Eastern European countries, European integration, international trade, dynamics of firms and labour, and sustainable economic development in leading journals. In 2008, he received the Slovenian state recognition in science (Zoisovo priznanje). 